\title{
Pelatihan Desain Kartu Ucapan Pada Usaha Florist
}

\author{
${ }^{1}$ Dian Pramana, ${ }^{2}$ Lilis Yuningsih, ${ }^{3}$ Wayan Agus Suka Dana \\ Institut Teknologi dan Bisnis STIKOM Bali ${ }^{1,2,3}$ \\ *Email: dian@stikom-bali.ac.id
}

\begin{abstract}
ABSTRAK
AVA Flowers \& Gift adalah salah satu toko florist yang ada di seputaran Kota Denpasar. Pelanggan utama dari florist ini adalah para remaja. Segmen pelanggan tersebut telah menjadikan usaha ini fokus pada penggunaan Instagram sebagai media pemasaran utamanya. Pendapatan rata-rata tiap bulan dari usaha florist ini mencapai $\mathrm{Rp} 2.000 .000$,- dan biasanya selalu meningkat pada hari-hari tertentu, seperti pada Hari Valentine atau pada Hari Ibu. Salah satu kendala yang dihadapi oleh mitra adalah dalam pembuatan kartu ucapan. Usaha florist ini harus menyiapkan biaya lebih untuk pembelian kartu terutama apabila pelanggan tidak menyukai desain kartu ucapan yang telah disiapkan. Berdasarkan permasalahan tersebut, kegiatan pengabdian masyarakat ini telah dilaksanakan dalam bentuk pelatihan untuk meningkatkan keterampilan mitra dalam desain grafis. Metode yang digunakan dalam kegiatan ini antara lain adalah sosialisasi, pelatihan dan pendampingan, serta evaluasi. Sebagai hasil dari kegiatan, saat ini usaha florist sudah mampu mendesain dan menghasilkan berbagai macam kartu ucapan yang dapat disesuaikan dengan kebutuhan dan keinginan dari pelanggan.
\end{abstract}

Kata kunci : florist, desain, kartu ucapan

ABSTRACT

AVA Flowers \& Gift is one of the flower shops around Denpasar City. The main customers of this flower shop are teenagers. The customer segment has made this business focus on using Instagram as the main marketing medium. The average monthly income from this flower shop business reaches IDR 2,000,000 and usually increases on certain days, such as Valentine's Day or Mother's Day. One of the services associated with partners is in making greeting cards. This florist business should be prepared to charge more for card purchases especially for customers who have no pre-prepared greeting card designs. Based on these problems, this community engagement activity has been carried out in the form of training to improve partners' skills in graphic design. The methods used in this activity include socialization, training and mentoring, and evaluation. As a result of this activity, the florist business is now able to design and produce various kinds of greeting cards that can be tailored to the needs and desires of the customers.

Key words: florist, design, greeting cards 


\section{PENDAHULUAN}

AVA Flowers \& Gift adalah salah satu toko florist (usaha perdagangan bunga profesional) yang ada di daerah Denpasar. Usaha ini terletak di Jalan Tukad Yeh Aya IX Gang Bima No 18, Renon - Denpasar. Pemilik usaha ini adalah Ni Putu Ayu Indah Wulandari yang telah merintis usaha ini sejak tahun 2016. Hingga kini usaha ini telah memiliki banyak pelanggan tetap yang berasal dari berbagai daerah di Kota Denpasar serta beberapa daerah lainnya di Pulau Bali. Target pelanggan utama dari usaha AVA Flowers \& Gift adalah para remaja. Selain menggunakan brosur, media pemasaran utama yang dilakukan oleh usaha ini adalah menggunakan media sosial Instagram, di mana media sosial tersebut cukup efektif dalam memasarkan usaha sesuai dengan segmen pasar yang diinginkan (Purwanti, 2020).

Omset rata-rata bulanan dari usaha florist ini mencapai Rp 2.000.000,- dan selalu meningkat pada Hari Valentine (14 Februari) dan Hari Ibu (22 Desember). Pada hari-hari tersebut banyak remaja yang memesan dan membeli bunga sebagai hadiah pemberian. Selain melayani penjualan, AVA Flowers \& Gift juga melayani pemesanan bunga untuk dekorasi acara penikahan, ulang tahun, bridal shower, serta berbagai kegiatan seremonial lainnya. Omset dekorasi untuk acara kegiatan-kegiatan tersebut mencapai $\mathrm{Rp}$ 2.000.000,- dalam satu acara.

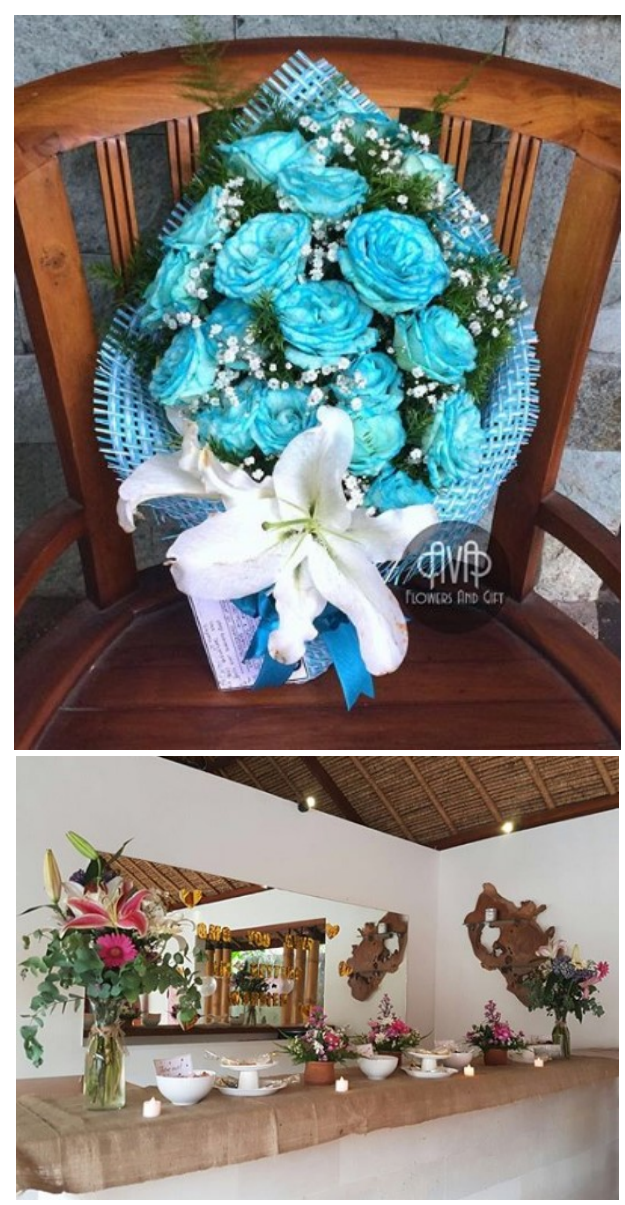

Gambar 1. Hasil Jasa Dekorasi Mitra 


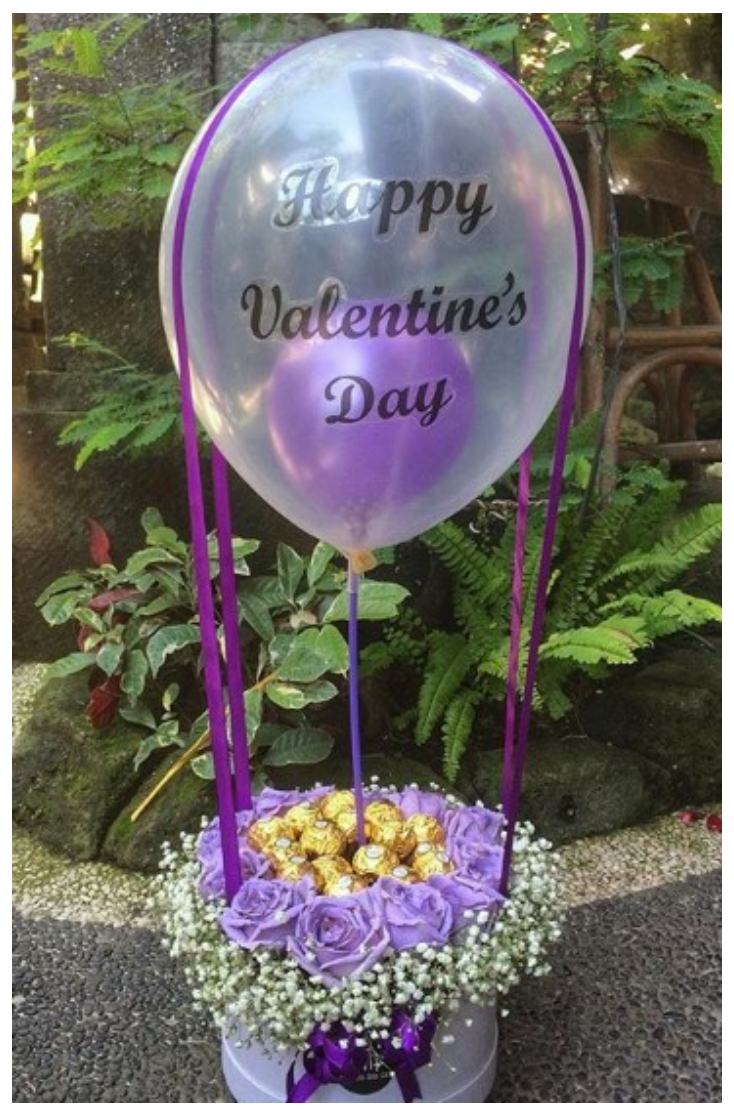

Gambar 2. Hasil Buket Bunga Mitra

Usaha florist AVA Flowers \& Gift mendapatkan pasokan bahan baku bunga dari daerah di luar kota Denpasar serta dari beberapa daerah di Pulau Jawa. Selain bahan baku bunga, pernak-pernik serta hiasan untuk dekorasi bunga dibeli pada toko souvenir dan beberapa di antaranya dibuat atau diproduksi sendiri. Salah satu pernak-pernik atau pelengkap yang umumnya ada pada buket bunga yang dijual adalah kartu ucapan. Saat ini pemilik usaha selalu membeli kartu ucapan di toko-toko souvenir. Kartu ucapan tersebut umumnya sudah dalam bentuk jadi dan hanya perlu dilengkapi dengan tulisan atau kalimat ucapan yang diinginkan pelanggan. Namun demikian, adakalanya desain kartu ucapan yang telah dibeli tersebut tidak sesuai dengan keinginan dari pelanggan. Sehingga tidak jarang, pemilik usaha harus mengeluarkan biaya lebih untuk membeli kartu ucapan baru yang lebih sesuai dengan keinginan pelanggan.

Berdasarkan permasalahan yang telah diuraikan di atas, dibutuhkan solusi yang tepat untuk membantu mengatasi hal tersebut. Pada kegiatan ini dilakukan pelatihan dan pendampingan bagi mitra dalam mempelajari dan mempraktekkan keterampilan desain grafis terutama dalam pembuatan desain kartu ucapan yang baik dan menarik dengan menggunakan tools Adobe Photoshop. Adobe Photoshop merupakan salah satu perangkat lunak untuk menyunting dan memanipulasi gambar yang canggih dan populer (Permana, 2013). Selain itu, fitur dari Adobe Photoshop juga cukup lengkap terutama bagi pemula yang ingin mempelajari keterampilan desain grafis (Ziveria, 2020). Dengan memiliki dasar keterampilan mendesain kartu ucapan, diharapkan mitra dapat menawarkan kartu ucapan yang sesuai dengan keinginan dan kebutuhan dari pelanggan, serta mampu berkomunikasi dan memberi ingatan secara visual kepada konsumen. (Bhaskara Gautama, 2019). Selain itu mitra juga tidak perlu mengeluarkan biaya lebih untuk membeli kartu ucapan pengganti yang baru.

\section{RUMUSAN MASALAH}

Berdasarkan uraian analisis situasi yang telah dijabarkan, maka dapat dirumuskan permasalahan prioritas yang dihadapi oleh mitra adalah belum adanya kemampuan yang mumpuni untuk menggunakan perangkat lunak desain grafis dalam membuat rancangan kartu ucapan. Hal tersebut menyebabkan mitra hanya bergantung pada desain kartu ucapan yang telah jadi dan dijual di 
pasaran. Namun tidak jarang kartu ucapan tersebut tidak sesuai dengan keinginan pelanggan, sehingga mitra harus mengeluarkan biaya lebih untuk membeli kartu ucapan baru yang sesuai dengan keinginan pelanggan. Dari permasalahan tersebut serta berdasarkan kesepakatan dengan mitra, maka pada kegiatan ini akan dilakukan pelatihan dan pendampingan pembuatan desain kartu ucapan menggunakan aplikasi Adobe Photoshop. Tujuan dari kegiatan ini adalah untuk menumbuh kembangkan pengetahuan dan kemampuan dasar mitra dalam membuat desain kartu ucapan menggunakan aplikasi Adobe Photoshop. Dengan demikian pengeluaran untuk biaya produksi kartu ucapan dapat lebih ditekan. Selain itu desain kartu ucapan yang menarik dan sesuai dengan keinginan dari pelanggan juga menjadi salah satu bentuk pelayanan yang dapat meningkatkan loyalitas dari pelanggan.

\section{METODE}

Kegiatan prioritas yang dilakukan adalah untuk mengatasi permasalahan dalam bidang produksi, khususnya dalam pembuatan kartu ucapan menggunakan Adobe Photoshop. Kegiatan ini kemudian dibagi atas tiga tahapan utama yaitu sebagai berikut:

Tahap pertama dari kegiatan ini adalah sosialisasi yang bertujuan untuk memberikan informasi dan pemahaman kepada mitra tentang alur proses dari kegiatan yang akan dilaksanakan. Selain itu pada tahap ini juga dilakukan diskusi untuk menentukan jadwal dan agenda kegiatan yang akan dilakukan.

Tahap kedua adalah tahap utama dalam kegiatan ini yaitu pelatihan desain kartu ucapan. Pelatihan ini berfokus pada pengenalan tools Adobe Photoshop, dasar- dasar desain grafis, mencari referensi desain, pembahasan copyright, serta praktik pembuatan desain kartu ucapan. Kegiatan ini dilaksanakan sebanyak 2 kali pertemuan tatap muka, dimana masingmasing pertemuan berdurasi sekitar 2-3 jam. Kegiatan ini dilakukan oleh seluruh tim pengabdian bersama dengan mitra.

Tahap terakhir dari kegiatan ini adalah evaluasi yang bertujuan untuk mengukur tingkat pemahaman dan kemampuan mitra sebagai hasil dari kegiatan pelatihan yang telah dilaksanakan. Parameter yang diukur adalah kuantitas dan kualitas dari desain kartu ucapan yang telah dihasilkan. Pengukuran ini menjadi salah satu parameter untuk mengetahui efektifitas dan tingkat keberhasilan kegiatan (Ardiyasa, 2020).

Prosedur kerja dalam pelaksanaan kegiatan ini dapat dilihat pada Gambar 3 berikut:

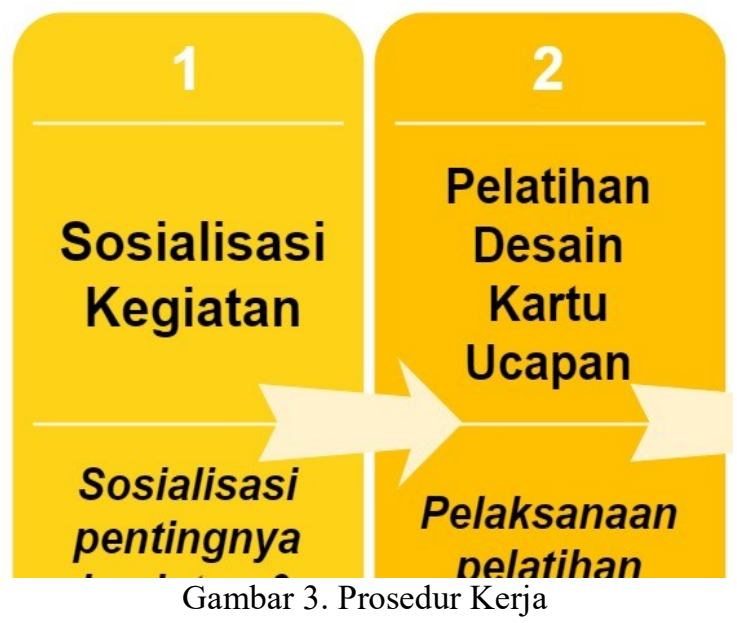

\section{PEMBAHASAN}

\section{Sosialisasi Kegiatan}

Kegiatan sosialisasi dilakukan pada hari Senin tanggal 13 Januari 2020. Pada kegiatan ini tim pelaksana menyampaikan latar belakang, manfaat, sasaran dan tujuan dari kegiatan. Tim juga menyampaikan gambaran teknis serta perihal yang harus 
dipersiapkan dalam pelaksanaan kegiatan. Dalam sosialisasi ini diputuskan bahwa alat berupa perangkat laptop dan jaringan internet akan disiapkan oleh tim pengabdian, namun mitra juga diijinkan apabila ingin menggunakan perangkat laptop sendiri. Selain itu dalam sosialisasi ini juga diputuskan jadwal serta lokasi pelaksanaan kegiatan pelatihan yang akan dilakukan.

\section{Pelatihan Desain Kartu Ucapan}

Pelatihan desain kartu ucapan ini dibagi menjadi 2 sesi. Sesi yang pertama dilakukan pada tanggal 15 Januari 2020 sedangkan sesi yang kedua dilaksanakan pada tanggal 16 Januari 2020. Setiap sesi pelatihan berdurasi kurang lebih selama 3 jam. Pada sesi pertama ini diawali dengan latihan mencari contoh desain kartu ucapan menggunakan mesin pencari Google. Pelatih memberikan penjelasan tentang bagaimana cara menggunakan kata kunci (keywords) yang tepat. Beberapa keywords yang digunakan adalah: desain kartu ucapan, ucapan ulang tahun, ucapan hari ibu, valentine gift cards, dan sebagainya. Selain itu mitra juga diberikan pemahaman tentang isu copyright atau hak cipta atas suatu gambar.
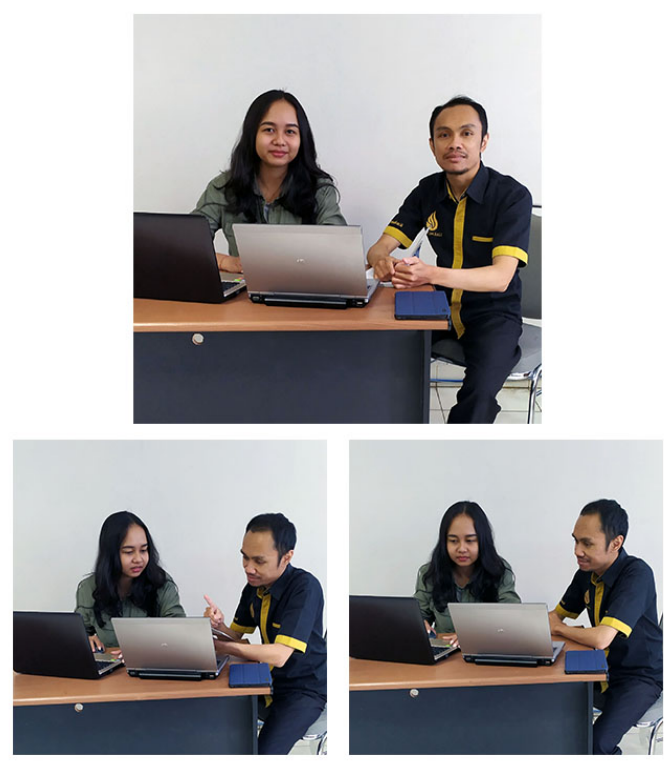

Gambar 4. Dokumentasi Kegiatan

Setelah selesai dengan materi pencarian gambar, fokus kegiatan pelatihan adalah pada pengenalan fungsi dasar tools serta antarmuka Adobe Photoshop CS6. Karena mitra sudah memiliki kemampuan dasar komputer, proses ini tidak memakan waktu yang panjang. Pada sesi pertama ini mitra dilatih untuk mengenali serta melakukan beberapa hal sebagai berikut:

- Memperkenalkan fungsi tombol, menu, serta shortcut umum yang digunakan dalam Adobe Photoshop.

- Membuat, menyimpan, dan membuka dokumen.

- Mengatur ukuran (resize) canvas dan image.

- Mengatur efek warna dan cahaya (tone, contras, color, dan sebagainya)

- Menambahkan gambar baru

- Membuat dan menyusun layer.

- Mengatur pilihan efek layer (blending, opacity, fill, channels, lock, duplicate, rasterize, merge layer, dan sebagainya).

- Menambahkan tulisan serta melakukan font style and formatting. 
- Menggunakan tools seperti marquee, lasso, crop, brush, eraser, gradient, type, dan tools umum lainnya.

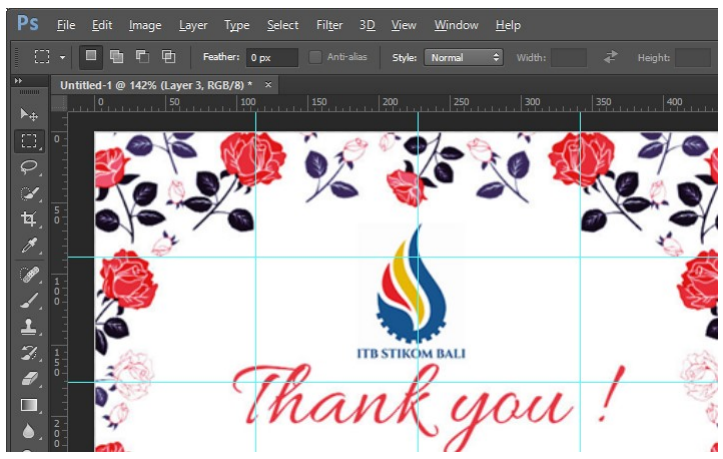

Gambar 5. Proses Menyusun Layer

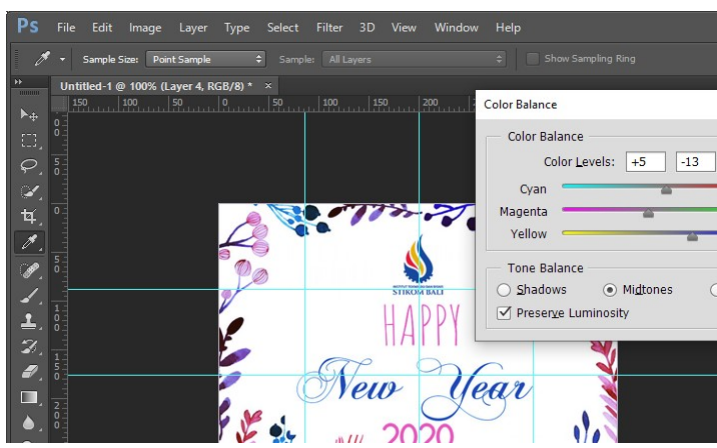

Gambar 6. Proses Mengatur Efek Warna

Pada sesi kedua mitra dilatih untuk memperdalam teknik desain yang telah disampaikan pada pelatihan sesi pertama.

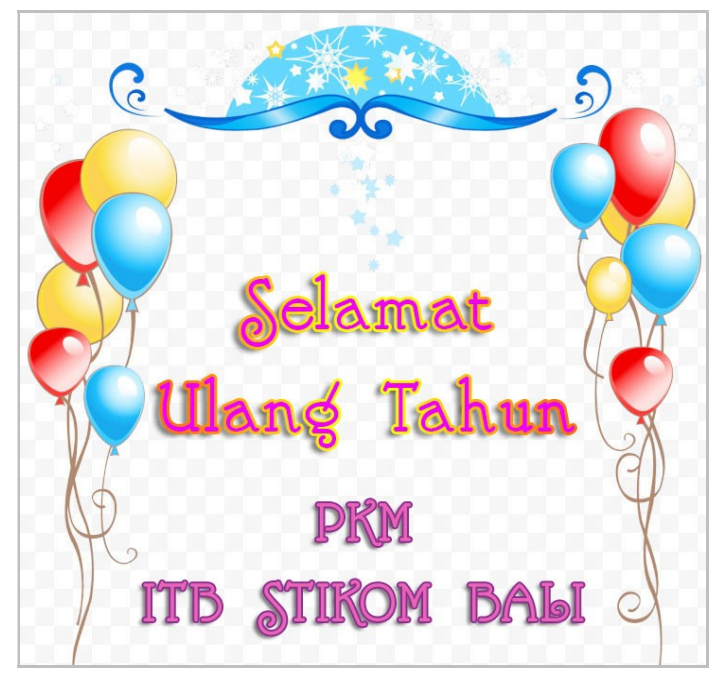

Gambar 7. Contoh Hasil Desain 1

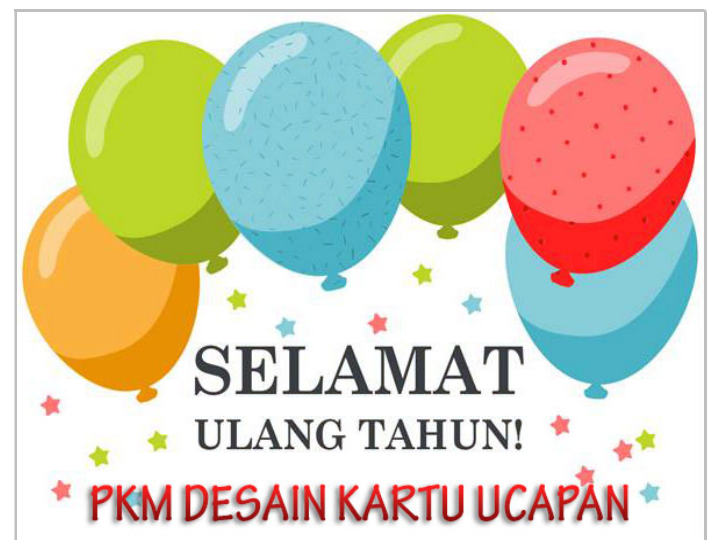

Gambar 8. Contoh Hasil Desain 2

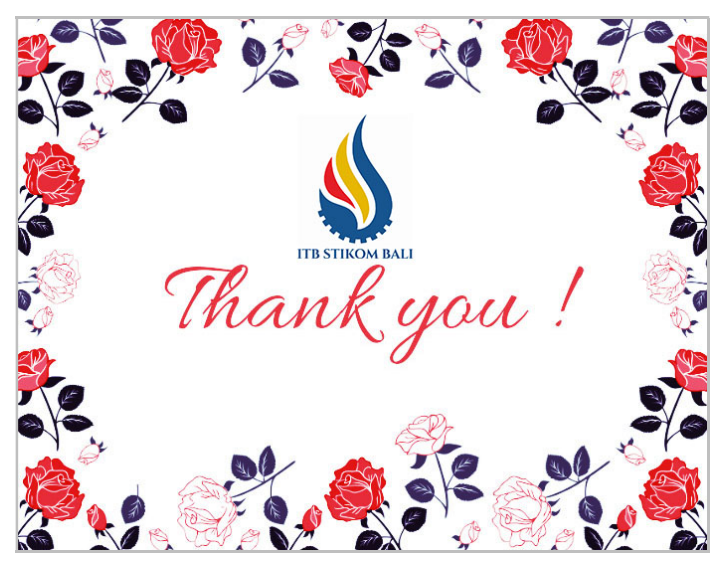

Gambar 9. Contoh Hasil Desain 3

\section{Evaluasi Kegiatan}

Evaluasi dilakukan untuk mengukur tingkat efektivitas kegiatan pelatihan yang telah dilakukan. Sebelum adanya kegiatan ini, mitra belum dapat mendesain kartu ucapan secara mandiri dan bergantung pada kartu yang dijual di pasaran. Setelah kegiatan ini dilaksanakan, kini mitra telah memiliki kemampuan yang cukup untuk mendesain kartu ucapan menggunakan Adobe Photoshop. Secara kuantitatif dapat dihitung semenjak kegiatan ini selesai dilakukan sampai dengan bulan Mei 2020, mitra telah menghasilkan 10 kartu ucapan yang didesain sesuai dengan pesanan pelanggan. Selain itu mitra sudah menghasilkan 23 template desain kartu 
ucapan yang dapat dimodifikasi kembali berdasarkan keinginan dari pelanggan.

Evaluasi juga dilakukan dengan cara pemberian angket yang berisi beberapa pernyataan yang berkaitan dengan proses serta dampak kegiatan (Linda Santiari, 2020).

Tabel 1. Pernyataan pada Angket

\begin{tabular}{|c|l|}
\hline No & \multicolumn{2}{|c|}{ Pernyataan } \\
\hline 1 & $\begin{array}{l}\text { Materi yang disajikan dapat menambah } \\
\text { wawasan saya untuk membuat desain kartu } \\
\text { ucapan. }\end{array}$ \\
\hline 2 & $\begin{array}{l}\text { Pelatihan disampaikan dengan menarik dan } \\
\text { interaktif sehingga mudah untuk dimengerti. }\end{array}$ \\
\hline 3 & $\begin{array}{l}\text { Konten pelatihan berguna dalam menjalankan } \\
\text { aktifitas saya sehari-hari yang berkaitan } \\
\text { dengan pekerjaan saya. }\end{array}$ \\
\hline 4 & $\begin{array}{l}\text { Waktu, fasilitas, dan teknik pelatihan yang } \\
\text { disampaikan sudah memadai. }\end{array}$ \\
\hline 5 & $\begin{array}{l}\text { Hasil kegiatan ini sesuai dengan sosialisasi } \\
\text { yang telah disampaikan sebelumnya. }\end{array}$ \\
\hline 6 & $\begin{array}{l}\text { Hasil kegiatan ini memuaskan dan sesuai } \\
\text { dengan harapan saya. }\end{array}$ \\
\hline 7 & $\begin{array}{l}\text { Hasil kegiatan ini akan seterusnya saya } \\
\text { manfaatkan dan bahkan akan saya } \\
\text { kembangkan lagi. }\end{array}$ \\
\hline
\end{tabular}

Mitra kemudian memberikan tanda centang (check) pada kolom sesuai dengan kondisi pada pernyataan yang disediakan. Kondisi tersebut terdiri dari jawaban: Ya, Tidak, dan Ragu-Ragu. Dari hasil angket dan tanya jawab yang telah dilakukan menunjukkan bahwa kegiatan pelatihan sudah berjalan dengan cukup baik dimana mitra telah mendapatkan manfaat dari kegiatan ini.

\section{SIMPULAN}

Mitra kini telah memiliki pengetahuan tentang cara membuat desain kartu ucapan menggunakan Adobe Photoshop. Mitra mampu menghasilkan desain kartu ucapan yang sesuai dengan kebutuhan dan keinginan dari pelanggan. Berdasarkan hasil evaluasi, diperoleh rekomendasi untuk kegiatan pengabdian berikutnya dibuat dengan durasi lebih panjang sehingga penyampaian materi pelatihan dapat menjadi lebih baik.

\section{UCAPAN TERIMA KASIH}

Ucapan terima kasih yang sebesarbesarnya disampaikan kepada segenap pihak yang telah membantu dalam proses dan pelaksanaan kegiatan pengabdian masyarakat yang berjudul "Pelatihan Desain Kartu Ucapan Pada Usaha Florist" ini. Terutama kepada Bapak Dr. Dadang Hermawan sebagai Rektor Institut Teknologi dan Bisnis STIKOM Bali yang telah memberikan kesempatan dan bantuan pendanaan sehingga kegiatan pengabdian ini dapat berjalan dengan baik. Selain itu ucapan terima kasih juga diberikan kepada Ibu Dr. Evi Triandini, M.Eng. serta segenap staf dan rekan sejawat yang telah membantu dalam pelaksanaan kegiatan ini sampai dengan tahap terakhir.

\section{DAFTAR PUSTAKA}

Purwanti, P.D., Harliantara, H. and Panuju, R. 2020. Strategi Komunikasi

Pemasaran Online Melalui Instagram Ditoko Bunga Citra Florist Surabaya. JESS (Journal of Education on Social Science), 4(1), pp.25-37.

Permana, B., 2013.36 Jam Belajar Komputer-Adobe Photoshop CS5 Extended. Elex Media Komputindo.

Ziveria, M., Samosir, R.S. and Rusli, M. 2020. Pelatihan Desain Grafis Menggunakan Perangkat Adobe Photoshop Untuk Manipulasi Foto Bagi Tim Teknologi Informasi YPU. ABDIMAS, 1(1), pp.1-11.

Bhaskara Gautama, I. M., Putri, DR. (2019). Perancangan Label Kemasan 
Aneka Kue dan Banner Sebagai Media

Promosi. WIDYABHAKTI Jurnal

Ilmiah Populer, 1(2), 14-20.

Ardiyasa, I. W., Ady Agus Arianto, I. K., \& Gita Praharsini, N. L. G. 2020. Penerapan dan Pelatihan Teknologi Informasi Pada Perangkat Desa di Kantor Kepala Desa Pengeragoan Jembrana Bali. WIDYABHAKTI Jurnal Ilmiah Populer, 2(2), 100-106.

Linda Santiari, N. P., Surya Rahayuda, I. G., Cahya Ayu Pratami, N. W., \& Muryatini, N. N. (2020). Pemanfaatan Teknologi Informasi Untuk Media Pemasaran Pada Kelompok Kerajinan Bali Kui. WIDYABHAKTI Jurnal Ilmiah Populer, 2(2), 82-86. 